\title{
Big Valuable Data in Supply Chain: Deep Analysis of Current Trends and Coming Potential
}

\author{
Samia Chehbi-Gamoura and Ridha Derrouiche \\ EM Strasbourg Business School, Université de Strasbourg, HuManiS EA 7308, \\ F-67000 Strasbourg, France.
}

\begin{abstract}
Today, Big Data Analytics (BDA) are definitely the key basis of competitiveness for enterprises in their Supply Chains. The outburst of data captured, accumulated and analyzed is impacting the value-added-chain at all levels from manufacturers to customers. In this paper, we develop a structured methodology to provide a deep analysis of Big Data Analytics methods across the Supply-Chain Operations Reference (SCOR) model processes. An exhaustive literature review is illustrated to afford a comprehensive Mind-Map cartography with a BDA-SCOR matching matrix. The proposed approach points to a number of research concerns that need to be addressed by research community. Outcomes of this study may highlight relevant guidelines for upcoming works of both academics and industrials. It highlights the need for collaborative Big Data to manage SCM more intelligently. Our objective is to provide an effective analysis to understand how Big Data Analytics become even more valuable for better Supply Chain Management.
\end{abstract}

Keywords: Big Valuable Data, Analytics, Supply Chain Management, SCOR model, Mind-Map cartography.

\section{Introduction}

There is no doubt; Big Data Analytics (BDA) is progressively becoming inevitable practice to extract more and more business values [1]. The main motive of Supply Chain (SC) managers is certainly to possess meaningful insights that allow them to better forecast, predict, reveal hidden patterns, and then to gain wider edge of competitiveness [2]. Henceforth, academics and industrials are aware that conventional databases are not capable to process such Big Data [3]. Analytics are reforming the way Supply Chain Management (SCM) handle acquired data internally; such as transactional information systems, and externally such as social networks, mobile devices, and IoT (Internet of Things) sensors [4].

Beyond considerate what Big Data earns, companies now are focusing on how analytics might be used to obtain business meaningful insights [5]. Given the variety and complexity of very large unstructured and high-dynamic datasets, this task is not trivial and may be very challenging [6].

Accordingly, we propose this paper with multifold purposes: (a) Foremost, it carried out a profound literature review across past and present patterns in academic publications. The bibliographical analysis is conducted by observing contributions, synthetizing knowledge, drawing tendencies, and making causality relationships by 
classifying intakes and highlighting further research opportunities. (b) Secondly, it provides a Mind-Map cartography of using BDA methods in Supply-Chain Operations Reference (SCOR) model as a clear synopsis of current research trends. (c) Lastly, this study draws future research trajectories and sheds light on the gaps that need to be overcome. Scholars can leverage this paper as a reference for future research opportunities, and SC specialists can use it as a methodology to benchmark BDA methods and measure impact in valuable information for SC.

This paper is structured as follows. We begin by introducing BDA methods and SCOR model reminder. We then develop the proposed methodology of bibliography analysis. Finally, we conclude by underlining the current trends of SCM-BDA researches, the untaken breaks, and the expected potential in the near future.

\section{Related Works and Research Gaps}

Analytics are ranged into several collections of methods, sub-methods and techniques that diverge in their objectives, prerequisites and applicability [7]. Hence, prior to hastily study applicability of these methods in SCM, there is a prerequisite to first understand their settings and features. The next sub-section offers a brief overview.

\subsection{Big Data Analytics Methods and Techniques}

The word 'value' in the context of BD denotes extraction of worthy information by investigating the accumulated data through transformation and processing. Aligned with [8], BDA are emerging as the 'next big thing' and is defined as a collection of technologies that handle, incorporate, and report massive data by transforming it into new insights not attainable with traditional technologies.

In one hand, academics are aware that decision makers progressively view in BDA an imperative driver of modernization and a substantial source of value creation for competitive benefit [9]. In fact, since 2014, there is an increasing emerging of research works: case studies ([10], [11], [12], etc.), original works ([13], [14], [15], etc.), surveys ([16], [17], etc.), and a variety of literature papers ([18, [19], [20], etc.). Likewise, industrials are attentive to the potential of analytics in management of SC. Indeed, the worldwide leader in research and advisory Gartner's ${ }^{\circledR}$ has mentioned in [21] that BDA appear among the Top 25 SC research topics for 2016. Forbes ${ }^{\circledR}$, also, argued in [22] that no single research topic in the last decade has as much effect on incumbent investments for industrials.

Approaches of BDA are numerous and may be alienated into several methods and sub-methods; to be employed solely or combined jointly [17]. Each method/submethod uses one or a mixture of statistical or mathematical techniques, up on the expected business value. According our literature review, the main root methods that concerned by SC are: Exploratory Data Analysis (EDA) [8], Confirmatory Data Analysis (CDA) [11], Qualitative Data Analysis (QDA) [23], and Real-Time Analysis (RTA) [24]. Based on the underlying methods, sub-methods and techniques can also be categorized into several groups, but given the breadth of these techniques, an 
exhaustive list exceeds the extent of a single paper. Though, a relevant sub-list which has already been used in the field of SC covers mainly: regression [25], optimization [26], induction [27], fuzzy logic [28], classification [10], aggregation [12], and so on.

\subsection{Supply Chain Operations Reference (SCOR) Model}

In order to expand in competiveness of companies, SCOR model was developed by Supply Chain Council (SCC) for designing and enhancing SCs. It offers standard frame for deciding, organizing and fulfilling SC processes [29]. Nevertheless, it is traditionally used in benchmarking studies [30]. SCOR model governs five processes; they are consecutively named and briefly described in table 1 .

Table 1. Brief definition of processes in SCOR Model (SCOR model V.9.0 [29])

\begin{tabular}{ll}
\hline Plan & Process that includes planning activities. \\
\hline Source & Process that includes procurement activities. \\
\hline Make & Process that includes transformation of contents or services. \\
\hline Deliver & Process that includes fulfilment of customer orders. \\
\hline Return & Process that includes reverse movements of goods from customers. \\
\hline
\end{tabular}

Based on pre-defined processes, SCOR can detect where action is required. It can also help to arrange more accurate projections. Accordingly, we base our study through SCOR processes. The next section describes step-by-step our methodology.

\section{Proposed Methodology}

\subsection{Data Collection}

By using Harzing's Publish or Purish V.5® [31], we queried out the more relevant and recent publications in the topic of BDA and SCM (from 2014 to 2017). Parameters of Harzing's serach request are itemized in table 2.

Table 2. Search request in Harzing's Publish or Purish V.5® [31]

\begin{tabular}{l|l}
\hline Query Date & $2017-03-22$ \\
\hline Maximum papers number & 100 \\
\hline Any of the words & $\{$ Big Data Analytics, Supply Chain, Management, Value $\}$ \\
\hline Publication type & Journal \\
\hline Since year & 2014 \\
\hline Publisher & All \\
\hline Search engine & Google Scholar Engine \\
\hline Location & Title, abstract, key words \\
\hline
\end{tabular}

Once the information were sorted, we then cleansed and filtered the academic database by deleting unwanted columns (ranking, types, ISSN) and rows (programs, 
books, technical reports, white papers, patents, literature reviews, unrelated researches, etc.). We kept only used columns (cites, authors, title, year, source, publisher, URL, countries) and rows (journals).

\subsection{Analysis and Findings}

By using the sorted list of last step, we reviewed each contribution and recorded a matrix that matched information with respect to BDA methods and SCOR processes. Discussion of our relevant findings and empirical results are in following sections.

Finding1: SCOR-BDA matching matrix. For each row (reference), we analyzed BDA methods, sub-methods and techniques (section 2.1), and then recorded matching cells with regard to SCOR processes according to table 1 . Table 3 below illustrates the SCOR-BDA matrix as applied to the collected bibliographical dataset.

Finding 2: Mind-Map Cartography of SCOR-BDA. We constructed cartography by using Mind-Mapping technique [32] with Coggle ${ }^{\circledR}$ tool [33]. The branching out in (Appendix, Fig.3) illustrates that all defined methods are employed in all SCOR processes but not with the same techniques. For instance, the FUzzy Logic technique (FUL) is used in Data Statistical-inference Methods (DSM) in 'Make' process but not in 'Source' process. Another ascertainment; the process 'Deliver' is the most prolific branch regard to methods and techniques already addressed in literature.

Table 3. SCOR-BDA matching matrix according to the bibliographical dataset.

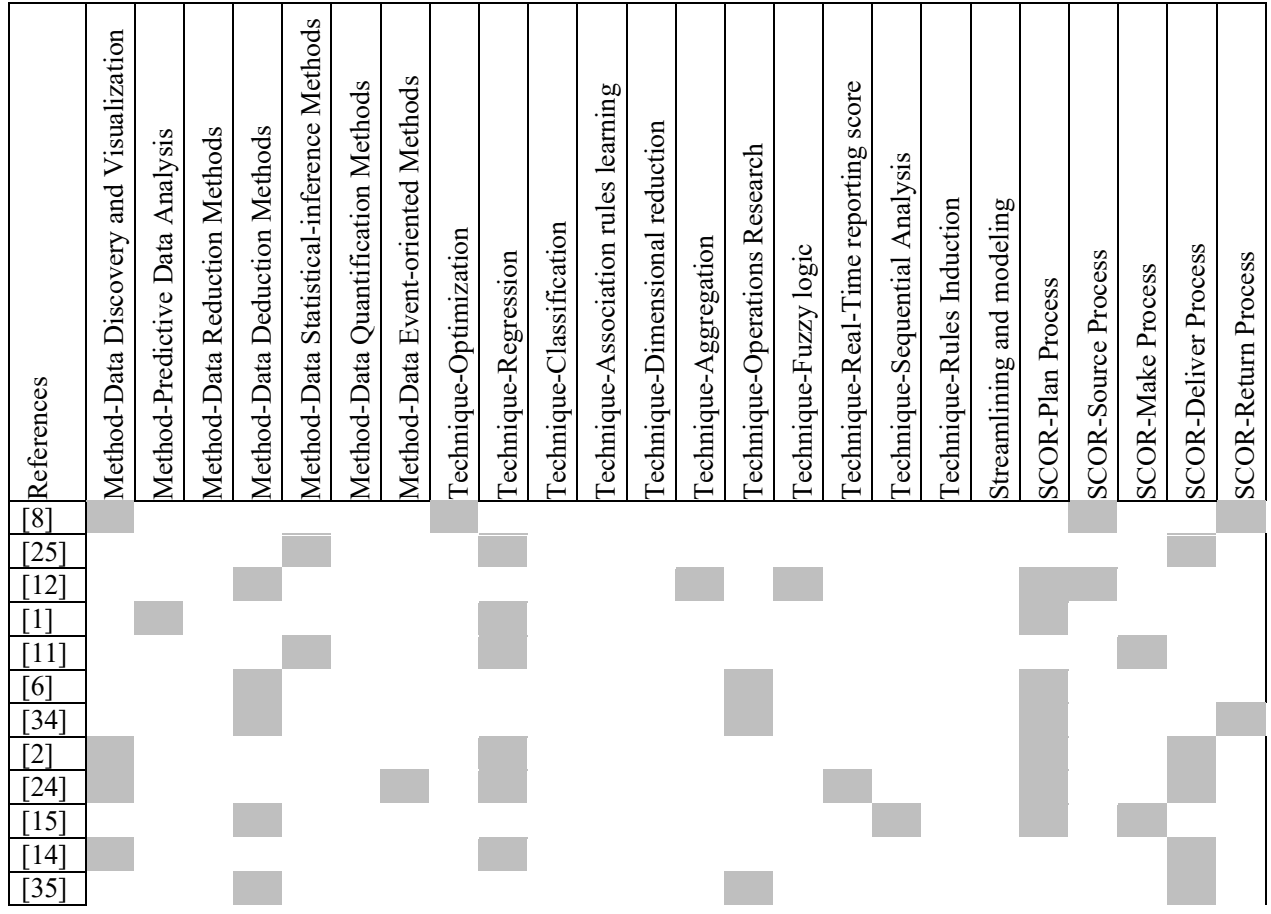




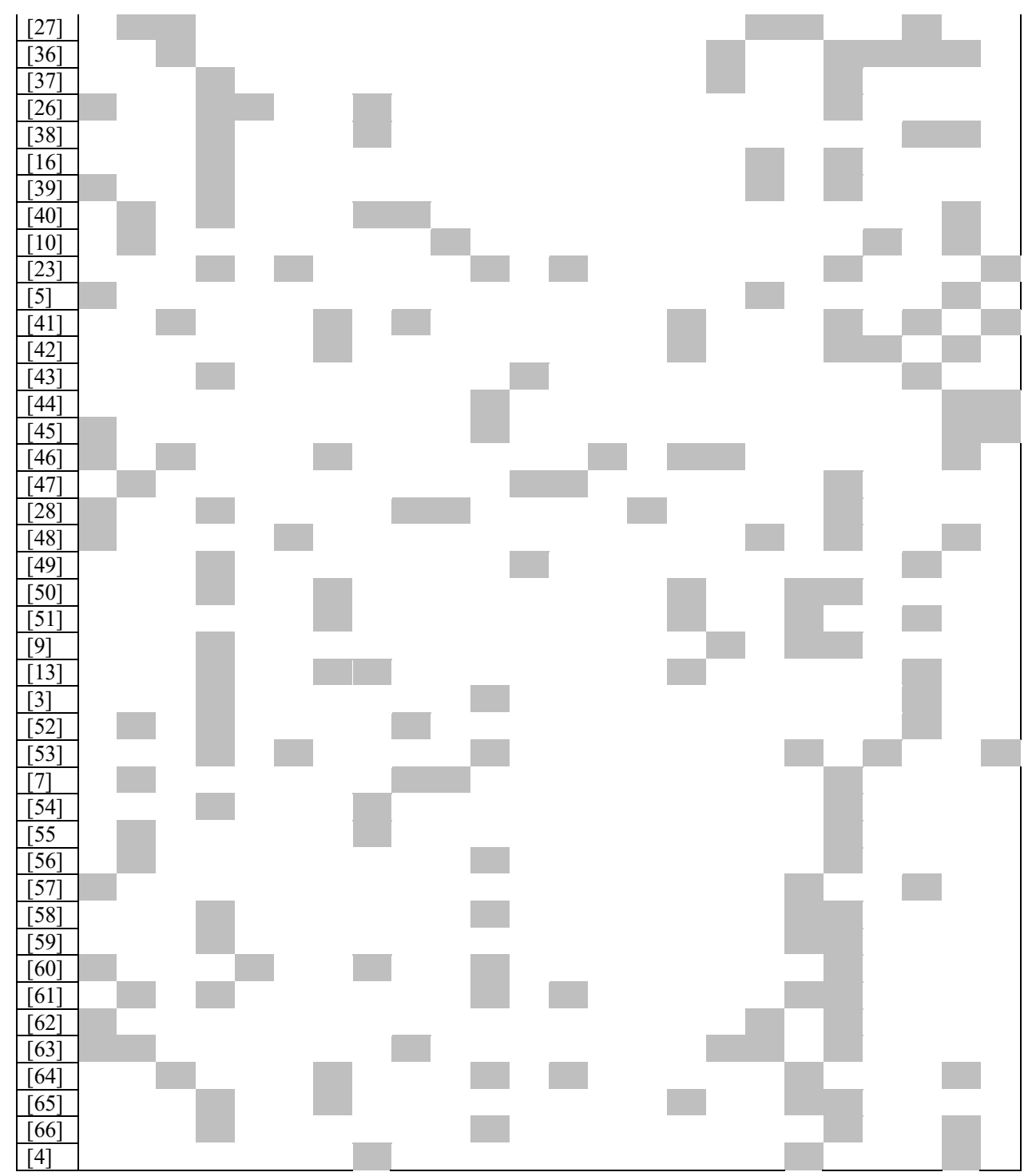

Finding 3: Overview of SCOR-BDA evolution. Bars diagrams in Fig.1; summarize the total number of publications for each process in SCOR, in the current three years (2014-2017).

As seen in Fig. 1, there is an exponential increase in the number of contributions for all SCOR processes with an overall exponential variation of $+0.064\left(\mathrm{R}^{2}=\sim 0,90\right)$. A few publications was issued in early 2014 (equal and less than $11 \%$ ), and at the end of $2015(\sim 11 \%-23 \%)$. However, in just two consecutive years later (2016 and 2017), publication rates have almost doubled for each year and each process (for instance; in 
plan process, the rate jumped from $11 \%$ to $26 \%$, and then to $53 \%$ ). This demonstrates that BDA tools have emerged as one of the fastest growing fields in SCM in recent years. On the other hand, as we observe an unequal growing interest for processes, we then broke down the total numbers by processes.

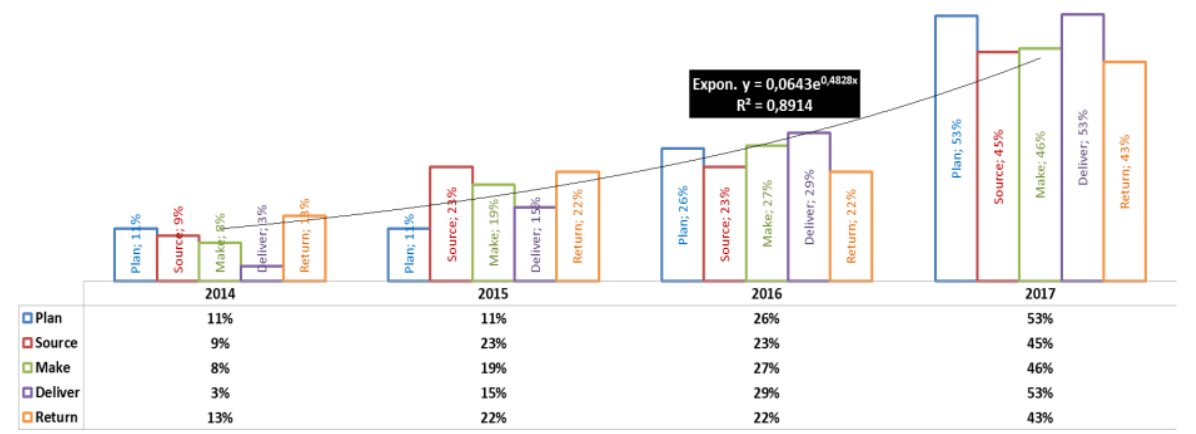

Fig. 1. Normalized total numbers of publications in BDA-SCOR matrix according to the bibliographical dataset (2014-2017)

Finding 4: Detailed view of SCOR-BDA evolution. Fig. 2 sorts the number of contributions for each process in the matrix BDA-SCOR of the selected dataset.

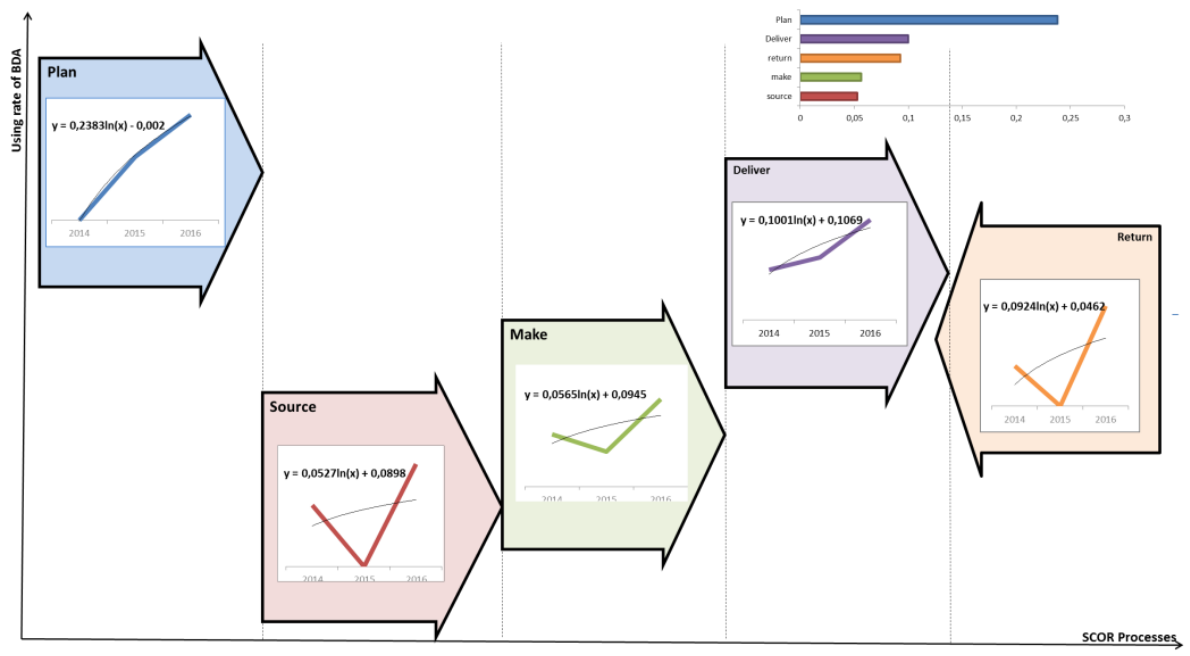

Fig. 2. Variations of BDA in SCOR processes according to the collected dataset (2014-2017)

As we observe in Fig. 2, all SCOR processes have adopted BDA, however with mixed paces. The evolution rate is sorted to make processes in a consecutive order: (1) Plan $(+0,238),(2)$ Deliver $(+0,100),(3)$ Return $(+0,092),(4)$ Make $(+0,056)$ and lastly (5) Source $(+0,052)$.

Subsequently, we assume that: the more operations are oriented inside the company (manufacturer), the less analytics are exploited. In other words, researchers need valuation of the data that are positioned at company's connectivity with the 
outside (mainly Deliver, Return and Plan). This indicates a lack of collaboration between companies in the process of valuing their data. We can explain this by the fact that these companies compete to extract as much value from data, but unfortunately each company acts separately. This point is very significant as it raises the need for collaborative Big Data to exploit it intelligently in SCM.

Furthermore, from a rational point of view, BDA are applied to processes differently because of the nature of these processes themselves. In instance, it seems normal to use analytics in Plan process as it is the most uncertain activity and then which necessities advanced techniques to obtain pertinent results. While for Make process, which is less unstable and better setup and maintained, analytics are less pertinent.

\section{Conclusion: Discussion and Future Trends}

It is true that the proposed approach may have some limits such as restriction in dataset collection. Indeed, we have collected data by the way of Harzing's Publish or Purish ${ }^{\circledR}$ tool which is itself limited in search queries and cannot combine searching engines. Despite this, the study allowed us to have a deep overview of the BDAs and their positioning in the SC processes.

The proposed approach offers a matching matrix and a Mind-Map cartography for BDA-SCOR benchmarking. Both tools can be largely taken up by academics and SC specialists to intuitively integrate them in orienting understanding. Furthermore, the empirical results presented in this paper argue that future researches should embrace more largely BDA, to continue redefining the focus of the contemporary management of SC. However, as the relevant literature shows, using BDA must not be hastily due to a fashion effect. SC specialists must establish a comprehensive schema to identify the objective of using analytics, the reason to expand volumes of exploited data and expressly the expected business value by using analytics.

Otherwise, the usage of BDA methods and techniques in the field of SC can still be significantly improved in at least three aspects: (a) more attention needs to be focused to BDA in manufacturing (Make process) and procurement (Source process). (b) A faultless and feasible deployment of BDA should be set up between all SC actors, thus, valuation of massive data would be conducted more accurately in terms of collaboration with decreasing of underlying costs, and timely truthful information can be provided for decision-makers (c) Upstream of the data processing step, this data should be collected, arranged, grouped, and summarized jointly by all SC actors. Rather than just accumulating and processing data, managers need to structure, and link their efforts to create a coherent picture of valuable data across overall the chain. This leads us to scrutinize more collaborative and intelligent Big Data utilization.

\section{Appendix}

Fig. 3 bellow illustrates the Mind-Map cartography according the collected dataset. 


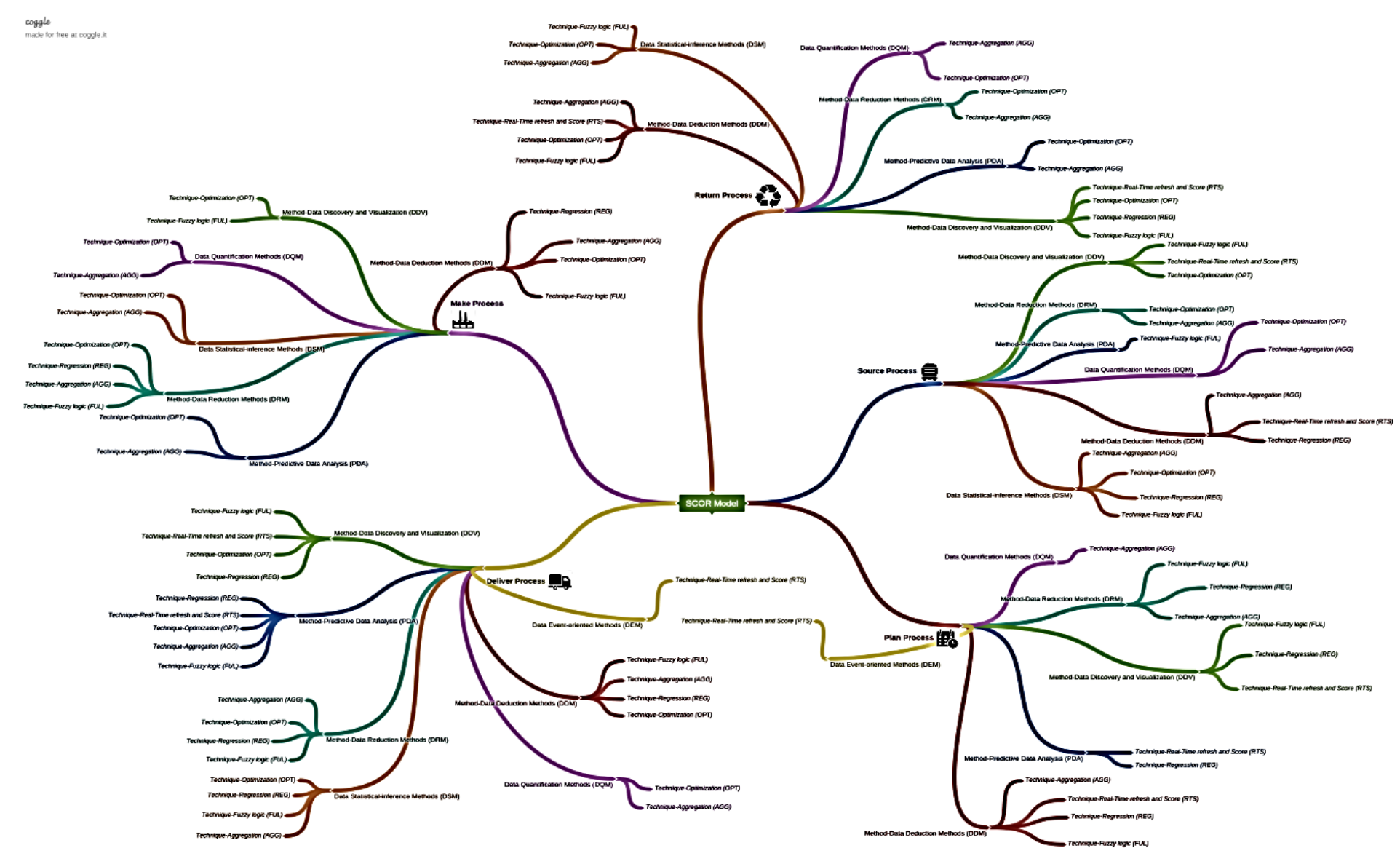

Fig. 3 MindMap of BDA- SCOR according to the bibliographical dataset (available under public access on [67]) 


\section{References}

1. Gunasekaran, A., Papadopoulos, T., Dubey, R., Wamba, S. F., Childe, S. J., Hazen, B., Akter, S.: Big data and predictive analytics for supply chain and organizational performance. Journal of Business Research, 70, 308--317 (2017)

2. Bendoly, E.: Fit, Bias, and Enacted Sensemaking in Data Visualization: Frameworks for Continuous Development in Operations and Supply Chain Management Analytics. Journal of Business Logistics, 37(1), 6--17 (2016)

3. Hazen, B. T., Boone, C. A., Ezell, J. D., Jones-Farmer, L. A.: Data quality for data science, predictive analytics, and big data in supply chain management: An introduction to the problem and suggestions for research and applications. International Journal of Production Economics, 154, 72--80 (2014)

4. Satpute, P., Tembhurne, O.: A Review of: Cloud Centric IoT based Framework for Supply Chain Management in Precision Agriculture. International Journal of Advance Research in Computer Science and Management Studies. 2(11), 175-180 (2014)

5. Ketter, W., Peters, M., Collins, J., Gupta, A.: Competitive benchmarking: an IS research approach to address wicked problems with big data and analytics. MIS Quarterly. No. ERS-2015-01 (2015)

6. Hazen, B. T., Skipper, J. B., Boone, C. A., Hill, R. R.: Back in business: Operations research in support of big data analytics for operations and supply chain management. Annals of Operations Research. 1--11 (2016)

7. Bi, Z., Cochran, D.: Big data analytics with applications. Journal of Management Analytics. 1(4), 249--265 (2014)

8. Zhao, R., Liu, Y., Zhang, N., Huang, T.: An optimization model for green supply chain management by using a big data analytic approach. Journal of Cleaner Production. 142, 1085--1097 (2017)

9. Cao, G., Duan, Y., Li, G.: Linking business analytics to decision making effectiveness: A path model analysis. IEEE Transactions on Engineering Management. 62(3), 384--395 (2015)

10. Chong, A. Y. L., Liu, M. J., Luo, J., Keng-Boon, O.: Predicting RFID adoption in healthcare supply chain from the perspectives of users. International Journal of Production Economics. 159, 66--75 (2015)

11. Dubey, R., Gunasekaran, A., Childe, S. J., Wamba, S. F., Papadopoulos, T.: The impact of big data on world-class sustainable manufacturing. The International Journal of Advanced Manufacturing Technology. 84(1-4), 631--645 (2016)

12. Wu, K. J., Liao, C. J., Tseng, M. L., Lim, M. K., Hu, J., Tan, K.: Toward sustainability: using big data to explore the decisive attributes of supply chain risks and uncertainties. Journal of Cleaner Production. 142, 663--676 (2017)

13. Zhang, Y., Zhang, G., Du, W., Wang, J., Ali, E., Sun, S.: An optimization method for shopfloor material handling based on real-time and multi-source manufacturing data. International Journal of Production Economics. 165, 282--292 (2015)

14. Rehman, U. M. H., Chang, V., Batool, A., Wah, T. Y.: Big data reduction framework for value creation in sustainable enterprises. International Journal of Information Management. 36(6), 917--928 (2016)

15. Giannakis, M., Louis, M.: A multi-agent based system with big data processing for enhanced supply chain agility. Journal of Enterprise Information Management. 29(5), 706$-727(2016)$

16. Emani, C. K., Cullot, N., Nicolle, C.: Understandable big data: A survey. Computer science review. 17, 70--81 (2015)

17. Chen, C. P., Zhang, C. Y.: Data-intensive applications, challenges, techniques and technologies: A survey on Big Data. Information Sciences. 275, 314--347 (2014)

18. Akter, S., Wamba, S. F.: Big data analytics in E-commerce: a systematic review and agenda for future research. Electronic Markets. 26(2), 173--194 (2016)

19. Schoenherr, T., Speier-Pero, C.: Data science, predictive analytics, and big data in supply chain management: Current state and future potential. Journal of Business Logistics. 36(1), 120--132 (2015) 
20. Duan, L., Xiong, Y.: Big data analytics and business analytics. Journal of Management Analytics. 2(1), 1--21 (2015)

21. Gartner.: Survey Analysis: What Does Increased Adoption of Big Data Mean to Supply Chain Strategists? Research Analysis, California, USA: Gartner, Inc. (2016)

22. Forbes.: 51\% Of Enterprises Intend To Invest More In Big Data. Research Press Report, California, USA.: Forbes Inc. (2016)

23. Luthra, S., Garg, D., Haleem, A.: Critical success factors of green supply chain management for achieving sustainability in Indian automobile industry. Production Planning \& Control. 26(5), 339--362 (2015)

24. Vera-Baquero, A., Colomo-Palacios, R., Molloy, O.: Real-time business activity monitoring and analysis of process performance on big-data domains. Telematics and Informatics. 33(3), 793--807 (2016)

25. Papadopoulos, T., Gunasekaran, A., Dubey, R., Altay, N., Childe, S. J., Fosso-Wamba, S.: The role of Big Data in explaining disaster resilience in supply chains for sustainability. Journal of Cleaner Production. 142, 1108--1118 (2017)

26. Dutta, D., Bose, I.: Managing a big data project: the case of ramco cements limited. International Journal of Production Economics. 165, 293--306 (2015)

27. Tan, K. H., Zhan, Y., Ji, G., Ye, F., Chang, C.: Harvesting big data to enhance supply chain innovation capabilities: An analytic infrastructure based on deduction graph. International Journal of Production Economics. 165, 223--233 (2015)

28. Chang, H-T., Mishra, N., Lin, C.: C. IoT Big-Data Centred Knowledge Granule Analytic and Cluster Framework for BI Applications: A Case Base Analysis. PLoS ONE. 10(11) (2015)

29. Supply Chain Council (SCC).: Supply Chain Operations Reference Model: Release 11.0. New York: Supply Chain Council (SCC). (2012)

30. Jamehshooran, G. B., Shaharoun, M., Haron, N. H.: Assessing supply chain performance through applying the SCOR model. International Journal of Supply Chain Management. 4(1) (2015)

31. Harzing. Harzing's Publish Or Perish. 02 19, 2017. http://www.harzing.com/ (accessed 03 22, 2017).

32. mindmapping.com. Mind Mapping. 3112 2016. http://www.mindmapping.com/fr/ (accès le 0325,2017$)$.

33. Coggle.it. Coggle Mind-Map. 3112 2016. https://coggle.it (accès le 03 25, 2017).

34. Song, M. L., Fisher, R., Wang, J. L., Cui, L. B.: Environmental performance evaluation with big data: Theories and methods. Annals of Operations Research. 1--14 (2016)

35. Wedel, M., Kannan, P. K.: Marketing analytics for data-rich environments. Journal of Marketing. 80(6), 97--121 (2016)

36. Li, J., Tao, F., Cheng, Y., Zhao, L.: Big data in product lifecycle management. The International Journal of Advanced Manufacturing Technology. 81(1-4), 667--684 (2015)

37. Miklos, A., Vasarhelyi, A. K., Tuttle, B. M.: Big Data in Accounting: An Overview. Accounting Horizons. 29(2), 381--396 (2015)

38. Xu, J., Huang, E., Chen, C. H., Lee, L. H.: Simulation optimization: a review and exploration in the new era of cloud computing and big data. Asia-Pacific Journal of Operational Research. 32(03) (2015)

39. Alles, M. G.: Drivers of the use and facilitators and obstacles of the evolution of big data by the audit profession. Accounting Horizons. 29(2), 439-449 (2015)

40. Phillips-Wren, G., Hoskisson,: A. An analytical journey towards big data. Journal of Decision Systems. 24(1), 87--102 (2015)

41. Lee, J., Ardakani, H. D., Yang, S., Bagheri, B.: Industrial big data analytics and cyberphysical systems for future maintenance \& service innovation. Procedia CIRP. 38, 3--7 (2015)

42. Vera-Baquero, A., Colomo-Palacios, R., Molloy, O.: Measuring and querying process performance in supply chains: an approach for mining big-data cloud storages. Procedia Computer Science. 64, 1026--1034 (2015)

43. Zhong, R. Y., Xu, C., Chen, C., Huang, G. Q.: Big Data Analytics for Physical Internetbased intelligent manufacturing shop floors. International Journal of Production Research. 1--12 (2015)

44. Xu, M., Cai, H., Liang, S.: Big Data and industrial ecology. Journal of Industrial Ecology. 19(2), 205--210 (2015) 
45. Chae, B. K.: Big data and IT-enabled services: ecosystem and coevolution. IT Professional. 17(2), 20--25 (2015)

46. Hsu, C. Y., Yang, C. S., Yu, L. C., Lin, C. F., Yao, H. H., Chen, D. Y., Robert, L. K., Chang, P. C.: Development of a cloud-based service framework for energy conservation in a sustainable intelligent transportation system. International Journal of Product. International Journal of Production Economics. (164), 454--461 (2015)

47. Zakir, J., Seymour, T., Berg, K.: Big data analytics. Issues in Information Systems. 16(2), $81--90(2015)$

48. Donnelly, C., Simmons, G., Armstrong, G., Fearne, A.: Digital loyalty card 'big data'and small business marketing: Formal versus informal or complementary? International Small Business Journal. 33(4), 422--442 (2015)

49. Gölzer, P., Simon, L., Cato, P., Amberg, M.: Designing global manufacturing networks using Big Data. Procedia CIRP. 33, 191--196 (2015)

50. Vera-Baquero, A., Colomo-Palacios, R., Molloy, O., Elbattah, M.: Business process improvement by means of Big Data based Decision Support Systems: a case study on Call Centers. International Journal of Information Systems and Project Management. 2182-7788 (2015)

51. O’Donovan, P., Leahy, K., Bruton, K., O’Sullivan, D. T. J.: An industrial big data pipeline for data-driven analytics maintenance applications in large-scale smart manufacturing facilities. Journal of Big Data. 2(1), 25 (2015)

52. Lee, J., Kao, H. A., Yang, S.: Service innovation and smart analytics for industry 4.0 and big data environment. Procedia CIRP. 16, 3--8 (2014)

53. Govindan, K., Kaliyan, M., Kannan, D., Haq, A. N.: Barriers analysis for green supply chain management implementation in Indian industries using analytic hierarchy process International Journal of Production Economics. 147, 555--568 (2014)

54. Milliken, A. L.: Transforming big data into supply chain analytics. The Journal of Business Forecasting. 33(4), 23 (2014)

55. Schlegel, G. L.: Utilizing big data and predictive analytics to manage supply chain risk. The Journal of Business Forecasting. 33(4), 11 (2014)

56. Chae, B., Olson, D., Sheu, C.: The impact of supply chain analytics on operational performance: A resource-based view. International Journal of Production Research. 52(16), 4695--4710 (2014)

57. Lasi, H., Fettke, P., Kemper, H., Feld, T., Hoffmann, M.: Industry 4.0. Business \& Information Systems Engineering. 6(4), 239--242 (2014)

58. Baars, H., Felden, C., Gluchowski, P., Hilbert, A., Kemper, H. G., Olbrich, S.: Shaping the next incarnation of business intelligence. Business \& Information Systems Engineering. 6(1), 11--16 (2014)

59. Vera-Baquero, A., Colomo-Palacios, R., Molloy, O.: Towards a process to guide Big data based decision support systems for business processes. Procedia Technology. 16, 11--21 (2014)

60. Chae, B. K., Yang, C., Olson, D., Sheu, C.: The impact of advanced analytics and data accuracy on operational performance: A contingent resource based theory (RBT) perspective. Decision Support Systems. 59, 119--126 (2014)

61. Stefanovic, N.: Proactive supply chain performance management with predictive analytics. The Scientific World Journal. 17 (2014)

62. Bhimani, A., L. Willcocks.: Digitisation, 'Big Data' and the transformation of accounting information. Accounting and Business Research. 44(4), 469--490 (2014)

63. Chae, B. K. A.: Complexity theory approach to IT-enabled services (IESs) and service innovation: Business analytics as an illustration of IES. Decision Support Systems. 57, 1-10 (2014)

64. Yesudas, M., Menon, G., Ramamurthy, V.: Intelligent operational dashboards for smarter commerce using big data. IBM Journal of Research and Development. 58(5/6), 13--1 (2014)

65. Bärenfänger, R., Otto, B., Österle, H.: Business value of in-memory technology-multiplecase study insights. Industrial Management \& Data Systems. 114(9), 1396--1414 (2014)

66. Zhu, J., Huang, Z.: Banks' Micro Enterprises Loan Credit Risk Decision-making Model Innovation in the Era of Big Data and Internet Finance. Journal of Management and Strategy. 5(2), 63 (2014) 
67. samiagamoura.com. SCOR-BDA Mind-Map. Vers. $1.0 .02 \quad 20,2017$. http://www.samiagamoura.com/mes-outils-my-coggle-mind-maps.html (accessed 0322 , 2017) 